\title{
PENERAPAN BLENDED LEARNING BERBASIS APLIKASI SCHOOLOGY SEBAGAI UPAYA UNTUK MENINGKATKAN HASIL BELAJAR ADMINISTRASI HUMAS DAN KEPROTOKOLAN
}

\author{
Efi Nur Fidiatun,C.Dyah Sulistyaningrum I*,Patni Ninghardjanti
}

\author{
Program Studi Administrasi Perkantoran ,FKIP, Universitas Sebelas Maret Surakarta
}

\begin{abstract}
Abstrak: Tujuan penelitian ini adalah untuk mengetahui peningkatan hasil belajar peserta didik kelas XII AP 3 mata pelajaran administrasi humas dan keprotokolan di SMK Negeri 1 Surakarta melalui penerapan model pembelajaran blended learning berbasis aplikasi schoology. Jenis penelitian ini adalah Penelitian TIndakan Kelas (PTK). Berdasarkan hasil penelitian, dapat disimpulkan bahwa penerapan model pembelajaran blended learning berbasis aplikasi schoology dapat meningkatkan hasil belajar peserta didik. Sebelum diterapkan model pembelajaran blended learning berbasis aplikasi schoology nilai rata-rata kelas pada ranah kognitif 66,84 persentase ketuntasan $29,03 \%$, ranah afektif persentase ketuntasan $64,52 \%$ dengan rata-rata nilai yaitu B, ranah psikomotorik rata-ratanya adalah 69,81 dengan persentase ketuntasan $48,39 \%$. Pada siklus I hasil belajar peserta didik yaitu rata-rata kelas pada ranah kognitif 80,26 dengan persentase ketuntasan 87,10\%, ranah afektif persentase ketuntasan $90,32 \%$ dengan rata-rata nilai yaitu $\mathrm{B}$, ranah psikomotorik rata-ratanya adalah 79,68 dengan persentase ketuntasan $80,65 \%$. Pada siklus II hasil belajar peserta didik yaitu rata-rata kelas pada ranah kognitif 85,29 atau dengan persentase ketuntasan $100 \%$, ranah afektif persentase ketuntasan $100 \%$ rata-rata nilai yaitu B, ranah psikomotorik rata-ratanya adalah 85,03 persentase ketuntasan $100 \%$.
\end{abstract}

Kata Kunci : blended learning, schoology, hasil belajar

Abstract: The purpose of this study is to determine the improvement of learning outcomes of students class XII AP 3 subjects of public relations administration and protocol in SMK Negeri 1 Surakarta through the application of learning models based bladed learning applications schoology. The type of research is Classroom Action Research (CAR).. Based on the results of the study, it can be concluded that the application of bladed learning model based on the application of schoology can improve learning outcomes of learners. Before applied learning model of bladed learning application based on schoology grade average grade in cognitive domain 66,84 percentage of $29,03 \%$ completeness, affective domain of $64,52 \%$ mastery percentage with mean value that is $\mathrm{B}$, psychomotor realm is 69,81 with a percentage of completeness of $48.39 \%$. In the first cycle of learning outcomes of learners is the 
average class in the cognitive domain of 80.26 with the percentage mastery $87.10 \%$, affective domain percentage mask $90.32 \%$ with the average value of $\mathrm{B}$, the average psychomotor realm is 79,68 with the percentage masked $80.65 \%$. In the second cycle of learning outcomes of learners is the average class in the cognitive domain of 85.29 or with $100 \%$ completeness percentage, affective domain percentage mastery $100 \%$ average value of $\mathrm{B}$, the average psychomotor realm is 85.03 percentage of $100 \%$.

Keywords: Blended Learning, Schoology, Learning Result

\section{PENDAHULUAN}

Perkembangan zaman menjadikan SDM untuk dapat mengikuti perkembangan ilmu pengetahuan dan teknologi yang semakin berkembang melalui dunia pendidikan. Pendidikan memiliki satu aspek yang paling penting dan mendasar dalam kehidupan manusia. Pemerintah diharapkan mampu membuat sistem pendidikan yang sistematis dan unggul sehingga diharapkan dapat meningkatkan kualitas pendidikan. Media pembelajaran merupakan bagian yang tidak dapat dipisahkan dan suatu integrasi terhadap metode belajar yang dipakai (Mumtahanah, 2014: 95);

(Mustafidah \& Aryanto, 2010: 89). Sekolah Menengah Kejuruan (SMK) sebagai satuan pendidikan pada jenjang pendidikan menengah. Berdasarkan observasi dan wawancara yang peneliti lakukan di SMK Negeri 1 Surakarta terhadap proses pembelajaran pada tanggal 17 Maret 2017 diperoleh keadaan proses pembelajaran sebagai berikut: 1) Tenaga pendidik dalam menyampaikan materi masih sering menggunakan metode ceramah 2) Penggunaan media pembelajaran masih belum maksimal, sehingga peserta didik kurang antusias dalam pembelajaran, 3) Pembelajaran masih menggunakan buku teks biasa, sehingga pembelajaran kurang menarik minat dan memotivasi peserta didik untuk belajar, 4) Belum dimanfaatkannya media dalam mata pelajaran administrasi humas keprotokolan di sekolah tersebut, serta 5) hasil belajar peserta didik masih rendah.

Hasil belajar merupakan tolak ukur pemahaman peserta didik yang melakukan tes yang sebelumnya telah melakukan suatu pembelajaran. Kunandar (2013: 62) menyatakan bahwa "hasil belajar adalah kompetisi atau kemampuan tertentu baik, kognitif, afektif, maupun psikomotorik yang dicapai atau dikuasia peserta didik setelah mengikuti proses belajar mengajar”. Menurut Syah (2011: 142) 
fungsi-fungsi evaluasi hasil belajar adalah 1) Fungsi administratif untuk penyusunan daftar nilai dan pengisian buku raport. 2) Fungsi promosi untuk menetapkan kenaikan. 3) Fungsi diagnistik untuk mengidentifikasi kesulitan belajar peserta didik dan merencanakan program perbaikan pengajaran.

4) Sumber data BP untuk memasok data peserta didik tertentu yang memerlukan bimbingan dan penyuluhan. 4) Bahan pertimbangan pengembangan pada yang akan datang meliputi pengembangan kurikulum, metode, dan alat-alat PBM. Menurut Bloom dalam Sudjana (2010: 2223) mengemukakan bahwa klasifikasi dari hasil belajar adalah 1) Ranah kognitif, berkenaan dengan hasil belajar intelektual yang terdiri dari enam aspek yang meliputi pengetahuan, pemahaman, aplikasi, analisi, sintesis, dan evaluasi. 2) Ranah afektif, berkenaan dengan sikap yang terdiri dari lima aspek yang meliputi penerimaan, jawaban, penilaian, organisasi, dan internalisasi. 3) Ranah psikomotorik, berkenaan dengan hasil belajar yang berupa ketrampilan dan kemampuan bertindak, meliputi enam aspek yakni gerakan refleks, keterampilan gerak dasar, kemampuan perceptual, ketepatan, keterampilan kompleks, gerakan ekspresif dan interpretatif.

Menurut Dimyanti dan Mudjiono (2009:7) "pembelajaran adalah suatu persiapan yang dipersiapkan oleh guru guna menarik dan memberi informasi kepada peserta didik, sehingga dengan persiapan yang dirancang oleh guru dapat membantu peserta didik menghadapi tujuan". Pengertian pembelajaran menurut Warsita (2008: 85) "pembelajaran adalah suatu usaha untuk membuat peserta didik belajar atau suatu kegiatan untuk membelajarkan peserta didik".

Blended Learning adalah strategi pembelajaran yang memanfaatkan teknologi internet (ELearning) yang dikombinasikan dengan tatap muka di kelas Rizkiyah

Menurut Mosa dalam Rusman (2011: 242) menyampaikan bahwa pola belajar yang dicampurkan adalah dua unsur utama yakni pembelajaran di kelas pembelajaran di sekolah melalui komunikasi.

\section{METODE PENELITIAN}

pembelajaran online ini terdapat pembelajaran menggunakan jaringan internet yang di dalamnya ada 
pembelajaran berbasisi web. Sehingga dapat disimpulkan bahwa Blended Learning adalah pembelajaran yang menggabungkan antara pembelajaran tatap muka dengan pembelajaran berbasis komputer yang dapat diakses secara online maupun offline.

Shoology merupakan situs yang dapat diakses melalui internet dengan menggabungkan jejaring sosial dan LMS. Dengan menggunakan schoology guru dapat mengasah pola pikir peserta didik untuk berfikir secara kreatif dan kritis. Schoology juga dapat berfungsi untuk

$$
\text { menyelesaikan masalah }
$$

dalam Jenis penelitian yang dilakukan oleh peneliti adalah Penelitian Tindakan Kelas (PTK). Subyek penelitian ini adalah peserta didik kelas XII AP 3 di SMK Negeri 1 Surakarta Tahun Ajaran 2017/2018 yang berjumlah 31 peserta didik. Penelitian ini dilaksanakan dengan melibatkan guru mata pelajaran administrasi humas dan keprotokolan, peneliti dan partisipasi peserta didik. Teknik pengumpulan data dilakukan melalui beberapa kegiatan berupa: observasi, wawancara, tes, dan dokumentasi. Prosedur penelitian meliputi tahap: perencanaan tindakan, pelaksanaan tindakan, observasi dan interpretasi, dan analisis dan refleksi.

\section{PEMBAHASAN}

\section{Pra Siklus}

\section{a. Ranah Kognitif}

Hasil belajar ranah kognitif diukur dari hasil belajar, data tersebut didapat dari ulangan tengah semester peserta didik kelas XII AP 3 SMK Negeri 1 Surakarta, dengan data sebagai berikut :

Hasil Ranah Kognitif Pra Siklus

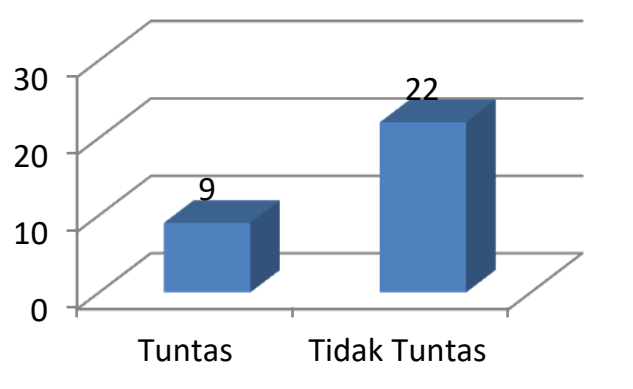

Gambar 1 Grafik Hasil Belajar Ranah Kognitif Pra Siklus

Berdasarkan hasil nilai Ulangan Tengah Semester (UTS) peserta didik menunjukan bahwa ketuntasan hasil belajar dengan KKM (Kriteria Ketuntasan Minimal = 75) yang dicapai pada pra siklus sebanyak 9 peserta didik dengan 
persentase $29,03 \%$ dengan hasil nilai rata-rata kelas yang diperoleh perserta didik mencapai 66,84. Dari hasil tersebut mengindikasikan bahwa dalam proses pembelajaran yang sedang berlangsung saat itu belum berhasil, sebab ketuntasan hasil belajar peserta didik belum mencapai indikator yang diharapkan.

\section{b. Ranah Afektif}

Hasil belajar ranah afektif menurut hasil observasi diukur dari lima aspek yang meliputi penerimaan, jawaban, penilaian, organisasi, dan internalisasi. Data prasiklus yang didapat adalah sebagai berikut :

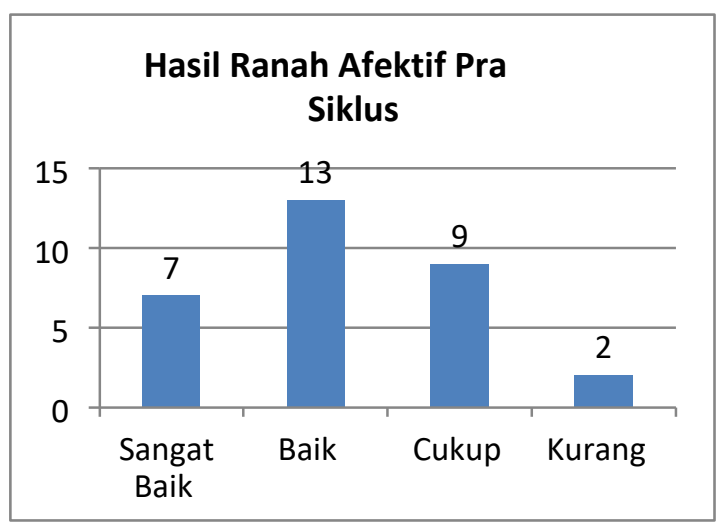

Gambar 2. Grafik Hasil Belajar Ranah Afektif Pra Siklus
Berdasarkan hasil tersebut masih banyak terdapat peserta didik yang belum mencapai nilai Baik dan terdapat peserta didik yang mendapat nilai Kurang, sehingga perlu adanya perbaikan pembelajaran agar seluruh peserta didik mendapat nilai minimal yaitu Baik.

\section{c. Ranah Psikomotorik}

Ranah psikomotorik diambil dari enam aspek yakni gerakan refleks, keterampilan gerak dasar, kemampuan perseptual, ketepatan, keterampilan kompleks, gerakan ekspresif dan interpretatif. Data prasiklus yang didapat adalah sebagai berikut :

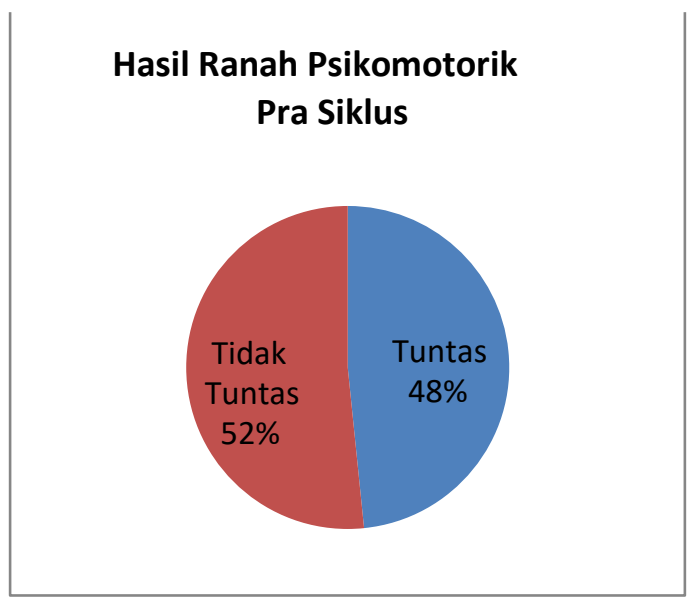


Berdasarkan hasil tersebut dapat disimpulkan bahwa hasil belajar ranah Psikomotorik masih terdapat peserta didik yang mendapat nilai kurang dari 75 atau KKM (Kriteria Ketuntasan Minimal=75), dengan persentase peserta didik tuntas adalah 48,39\%. Sehingga peserta didik masih banyak yang harus mendapat perbaikan..

\section{Siklus I}

\section{a. Ranah Kognitif}

Hasil belajar ranah kognitif diperoleh melalui ujian tertulis, dimana pelaksanaan ujian tertulis dengan aplikasi schoology dilaksanakan pada pertemuan setelah pelaksanaan tugas diskusi online. Kegiatan ini dilakukan untuk mengetahui sampai mana materi peserta didik pada pelajaran. Berikut hasil belajar peserta didik ranah kognitif kelas XII AP 3 SMK Negeri 1 Surakarta, dengan diperoleh hasil sebagai berikut :

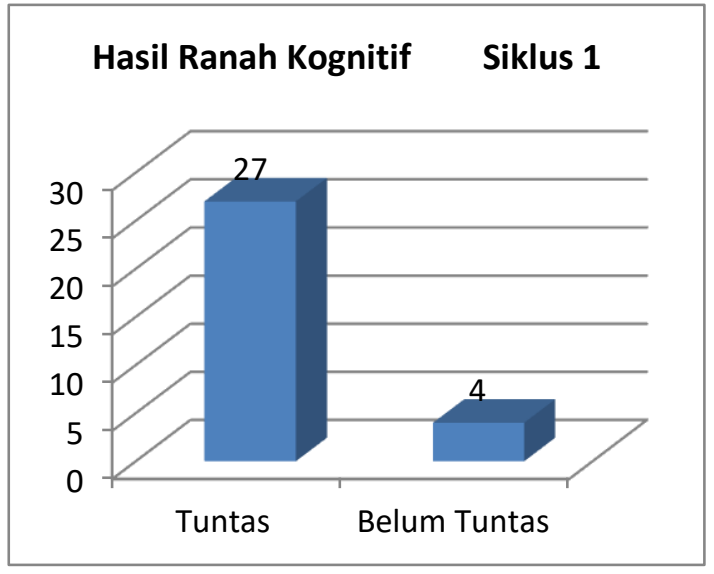

Gambar 4 Grafik Hasil Belajar Ranah Kognitif Siklus 1

Berdasarkan hasil evaluasi peserta didik menunjukan bahwa ketuntasan hasil belajar dengan KKM (Kriteria Ketuntasan Minimal =75) yang dicapai pada siklus I sebanyak 26 peserta didik dengan persentase $87.10 \%$ dengan nilai ratarata kelas yang diperoleh peserta didik mencapai 80,26. Dari hasil tersebut mengindikasikan bahwa dalam proses pembelajaran yang sedang berlangsung sudah berhasil, sebab ketuntasan hasil belajar peserta didik sudah mencapai indikator yang diharapkan. 


\section{b. Ranah Afektif}

Pada ranah afektif kriteria yang menjadi penilaian adalah perhatian peserta didik, hubungan peserta didik dengan guru, partisipasi peserta didik, dan keberanian peserta didik. Berikut adalah ranah afektif peserta didik kelas XII AP 3.

Berdasarkan hasil data olahan ranah afektif, peserta didik mengalami peningkatan dengan menggunakan model pembelajaran blended learning mengimplementasi aplikasi schoology. Dibuktikan dengan peserta didik sudah tidak ada yang mendapat nilai Kurang (K), akan tetapi masih belum mencapai target yang diinginkan karena masih terdapat peserta didik yang mendapatkan nilai Cukup (C) yaitu sebanyak 3 peserta didik. Sedangkan Baik (B) sebanyak 18 peserta didik dan Sangat Baik sebanyak 10 peserta didik.
Hasil Ranah Afektif Siklus 1

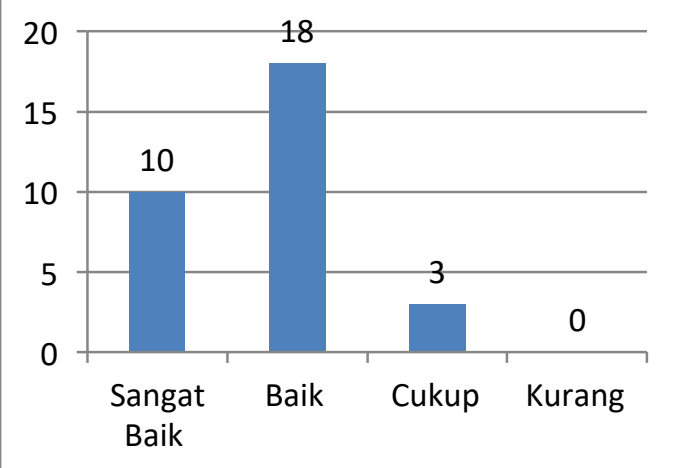

Gambar 5 Grafik Hasil Belajar Ranah Afektif Siklus 1

\section{c. Ranah Psikomotorik}

Pada ranah psikomotorik kriteria yang menjadi penilaian adalah kemampuan dalam menyebutkan dan mendeskripsikan dengan baik jawaban yang diinginkan guru. Berikut hasil belajar peserta didik ranah psikomotorik kelas XII AP 3 SMK Negeri 1 Surakarta.

Berdasarkan hasil data olahan siklus 1 pada ranah psikomotorik terjadi peningkatan dengan rata-rata kelas 79,68 dan persentase ketuntasan $80,65 \%$ dengan menggunakan media pembelajaran blended learning dengan mengimplementasi aplikasi 
schoology. Pada siklus I ini hasil dari peserta didik belum mencapai target ketuntasan yang diterapkan sebelumnya $(85 \%)$.

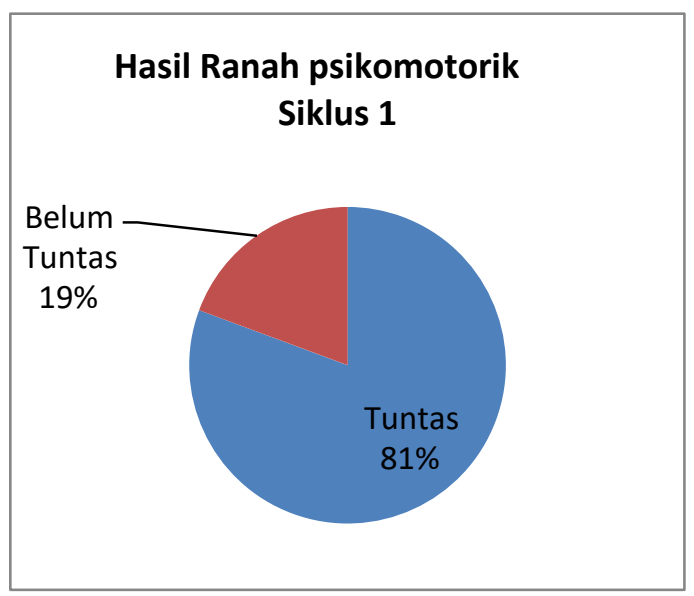

Gambar 6 Grafik Hasil Belajar Ranah Psikomotorik Siklus 1

\section{Siklus II}

\section{a. Ranah Kognitif}

Hasil belajar ranah kognitif diperoleh dari hasil evaluasi online lewat aplikasi schoology yang nilainya langsung masuk ke akun guru, pelaksanaan evaluasi tersebut masih sama dengan pelaksanaan siklus I. Kegiatan ini dilakukan untuk mengetahui sampai mana materi dan pengetahuan peserta didik saat pembelajaran. Berikut hasil belajar peserta didik ranah kognitif kelas XII AP 3 SMK Negeri

1 Surakarta.

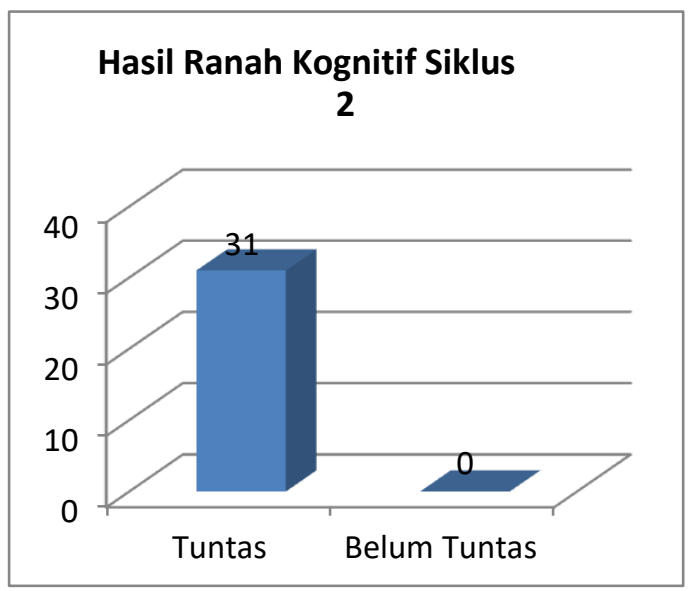

Gambar 7 Grafik Hasil Belajar Ranah Kognitif Siklus 2

Berdasarkan hasil evaluasi peserta didik menunjukan bahwa ketuntasan hasil belajar dengan KKM (Kriteria Ketuntasan Minimal =75) yang dicapai pada siklus II sebanyak 31 peserta didik dengan persentase $100 \%$ dengan nilai ratarata kelas yang diperoleh peserta didik mencapai 85,29. Dari hasil tersebut mengindikasikan bahwa dalam proses pembelajaran yang sedang berlangsung sudah berhasil, sebab ketuntasan hasil belajar peserta didik sudah mencapai indikator yang diharapkan atau 
semua peserta didik telah tuntas dalam pembelajaran.

\section{b. Ranah Afektif}

Berdasarkan hasil data olahan ranah afektif siklus 2, peserta didik mengalami peningkatan dengan menggunakan model pembelajaran blended learning mengimplementasi aplikasi schoology. Dibuktikan dengan peserta didik yang mendapat nilai minimal yaitu Baik (B). Sehingga dapat dikatakan seluruh peserta didik telah mencapai nilai tuntas dan pembelajaran dapat dikatakan berhasil.

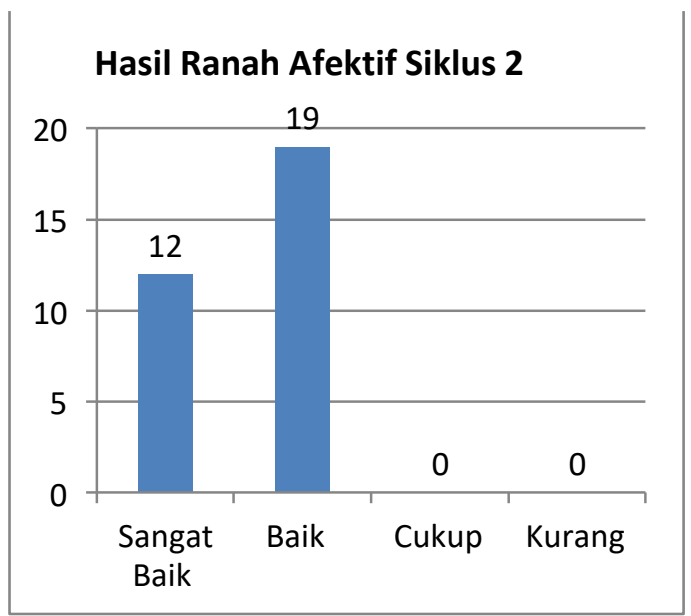

\section{c. Ranah Psikomotorik}

Berikut hasil belajar peserta didik ranah psikomotorik kelas XII AP 3 SMK Negeri 1 Surakarta. Berdasarkan hasil evaluasi peserta didik menunjukan bahwa ketuntasan hasil belajar dengan KKM (Kriteria Ketuntasan Minimal =75) yang dicapai pada siklus II sebanyak 31 atau semua peserta didik mencapai batas KKM yang ditentukan dengan persentase $100 \%$ dan nilai rata-rata kelas mencapai 85,29. Dari hasil tersebut mengindikasikan bahwa dalam proses pembelajaran yang sedang berlangsung sudah berhasil, sebab ketuntasan hasil belajar peserta didik sudah melebihi indikator yang diharpakan.

Gambar 8 Grafik Hasil Belajar

Ranah Afektif Siklus 2 
Hasil Ranah Psikomotorik

Siklus 2

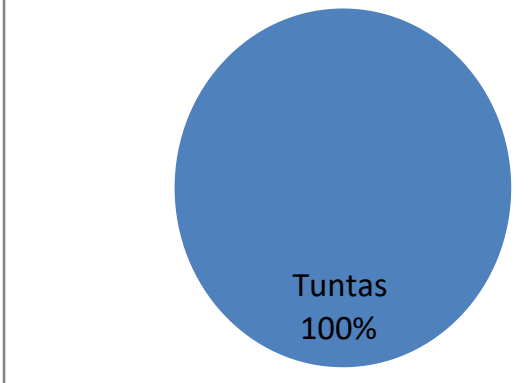

Gambar 9 Grafik Hasil Belajar Ranah Psikomotorik Siklus 2

\section{KESIMPULAN}

Peningkatan hasil belajar peserta didik siklus 1 dan siklus 2 dapat dilihat dari Hasil belajar peserta didik ranah kognitif pada pra siklus yaitu 29,03\%, kemudian pada siklus 1 mencapai $\quad 87,10 \%, \quad$ selanjutnya meningkat pada siklus 2 yaitu 100\% atau peserta didik mencapai batas ketuntasan semuanya. Hasil belajar peserta didik ranah afektif pada pra siklus yaitu peserta didik yang mendapatkan nilai Sangat Baik (SB) yaitu sebanyak 7 peserta didik, Baik (B) sebanyak 13 peserta didik, Cukup
(C) sebanyak 9 peserta didik kemudian Kurang sebanyak 2 peserta didik. Pada siklus 2 terjadi peningkatan dimana peserta didik yang memperoleh predikat Sangat Baik (SB) dan Baik (B) sebanyak 28 peserta didik dari 31 peserta didik. Selanjutnya pada siklus II peserta didik mengalami peningkatan yaitu peserta didik yang mendapat predikat Sangat Baik (SB) adalah 12 peserta didik dan predikat Baik (Baik) sebanyak 19 peserta didik. Hasil belajar ranah psikomotorik pada pra siklus yaitu 48,38\% kemudian pada siklus 1 persentase ranah psikomotorik peserta didik adalah $80,65 \%$, dan pada siklus 2 yairu $100 \%$ artinya semua peserta didik telah mencapai batas Kriteria Ketuntasan Minimal (KKM=75).

Saran yang diberikan adalah Guru hendaknya dapat memilih model pembelajaran yang cocok, Guru juga harus lebih up to date dengan perkembangan teknologi yang digunakan dalam pembelajaran, Peserta didik hendaknya lebih berpartisipasi aktif dalam kegiatan diskusi tatap muka maupun diskusi online, Peserta didik harus up to date dengan aplikasiaplikasi terkini yang berkaitan dengan pembelajaran, Peserta didik harus 


\section{DAFTAR PUSTAKA}

Dimyati \& Mudjiono. 2009. Belajar dan Pembelajaran. Jakarta: PT Rineka Cipta

Mumtahanah, Narutun. 2014. Penggunaan Media Visual Dalam Pembelajaran PAI. Jurnal Studi Keislaman. Vol. 4, No. 1, pp. 91-104.

Kunandar. 2013. Penilaian Auntentik (Penilaian Hasil Belajar Peserta Didik Berdasarkan Kurikulum 2013). Jakarta: PT Raja Grafindo Persada.

Rizkiyah, Apriliya. 2015. Penerapan Blanded Learning Untuk Meningkatkan Hasil Belajar Peserta didik Pada Mata Pelajaran Ilmu Bangunan di Kelas X TGB SMK Negeri 7 Surabaya. Jurnal Kajian Pendidikan Teknik Bangunan. Vol. 1, No.1, pp. 40-49.

Rusman. 2011. Pembelajaran Berbasis Teknologi Informasi dan Komunikasi. Jakarta: PT Raja Grafindo Persada.

Sudjana, Nana. 2010. Penilaian Hasil Proses Belajar Mengajar. Bandung: PT Remaja Rosdikarya.

Syah, Muhibbin. 2011. Psikologi Belajar. Jakarta: PT Raja Grafindo Persada.

Warsita, Bambang. 2008. Teknologi Pembelajaran Landasan \& Aplikasinya. Jakarta: Rineka Cipta. 
